\title{
MEDIA PROMOSI KESEHATAN KESIAPSIAGAAN MENGHADAPI VIRUS CORONA (COVID-19)
}

\author{
Emy Sutiyarsih $^{1 *}$, Elizabeth Yun Yun Vinsur ${ }^{2}$, Eli Lea Widhia Purwandhani ${ }^{3}$ \\ 1,2,3 STIKes Panti Waluya Malang \\ Alamat: Jalan Yulius Usman No.62, Malang 65117, \\ Telepon: 0341-369003, email: emymlg23@yahoo.com
}

\begin{abstract}
ABSTRAK
Kegiatan Program Kemitraan Masyarakat "Media Promosi Kesehatan Kesiapsiagaan Menghadapi Virus Corona (Covid-19)" diawali dengan pengkajian awal terhadap keadaaan di kota Malang. Pengkajian awal didapatkan permasalahan bahwa semakin bertambahnya angka kejadian penyakit Corona (Covid-19) di Kota Malang. Bedasarkan data dari Dinas Kesehatan Kota Malang, penambahan tersebut karena ada transmisi dari kerabat dekat atau keluarga pasien positif Covid-19. Kegiatan Promosi Kesehatan Kesiapsiagaan Menghadapi Virus Corona (Covid-19) diawali dengan pengisian pretest melalui googleform selanjutnya dilaksanakan Kegiatan penyampaian materi Kesiapsiagaan Menghadapi Virus Corona (Covid-19) secara daring dengan menunjukkan cara memakai dan melepas masker yang benar, cara mencuci tangan yang benar, pelaksanaan social distancing, Etika batuk dan bersin dengan menggunakan media video yang di share di grup WhatsApp ibu PKK RT 05, grup WhatsApp ibu PKK RT 06, grup WhatsApp ibu Wanita Katholik Wilayah Yohanes Pemandi 2X seminggu selama 1 bulan. Hasil postest menunjukkan ada peningkatan pengetahuan ibu-ibu tentang pencegahan penyebaran virus corona. Dengan adanya penambahan pengetahuan dan pengingkatan kesadaran masyarakat mengenai kesiapsiagaan menghadapi virus corona, diharapkan dapat meningkatkan kepatuhan dalam melakukan pencegahan penyebaran virus corona dalam kehidupan sehari-hari pada keluarga.
\end{abstract}

Kata Kunci: promosi, kesehatan, virus corona

\begin{abstract}
Community Partnership Program "Media Promotion of Health Awareness Facing Corona Virus (COVID-19)" begins with an initial assessment of the situation in Malang. Initial assessment was obtained that the increasing incidence of Corona disease (COVID-19) was found in Malang. Based on data from the Malang City Health Office, the addition is due to transmission from close relatives or families with positive COVID-19. Health Awareness Promotion Activities Facing Corona Virus (COVID-19) begins with pretest by google form. Furthermore, we provide material explanation of Corona Virus Preparedness (COVID-19) online by showing how to wear and remove the correct mask, how to wash hands with WHO standards, examples of social distancing, how to coughing and sneezing properly using video media shared in WhatsApp groups. WhatsApp group includes the empowerment of family welfare (Pemberdayaan Kesejahteraan Keluarga/PKK) group RT 05, RT 06, and the WKRI Group of John Baptism Region whose presentation was conducted twice a week in a month. Post-test results showed there was an increase in knowledge in each group about the prevention of the spread of coronavirus. The addition of knowledge and increased public awareness about the preparedness to face the corona virus, is expected to increase compliance in preventing the spread of coronavirus in daily life in their families.
\end{abstract}

Keywords: promotion, health, COVID-19 


\section{PENDAHULUAN}

Pada awal tahun 2020 wabah Pandemi COVID-19 merupakan peristiwa menyebarnya penyakit Coronavirus di berbagai belahan dunia. Penyakit ini disebabkan oleh Coronavirus jenis baru yang diberi nama SARS-CoV-2 (Susilo, 2020). Wabah COVID-19 pertama kali dideteksi di Kota Wuhan, Provinsi Hubei, Tiongkok pada bulan Desember 2019, dan ditetapkan sebagai pandemi oleh Organisasi Kesehatan Dunia (WHO) pada 11 Maret 2020. Hingga 23 April 2020, lebih dari 2.000.000 kasus COVID-19 telah dilaporkan di lebih dari 210 negara dan wilayah, mengakibatkan lebih dari 195,755 orang meninggal dunia dan lebih dari 781,109 orang sembuh (WHO, 2020). Update Corona 19 April 2020: jumlah kasus positif corona di Indonesia telah sebanyak 6.575 pasien. Di Jawa Timur pada tanggal 30 Juli 2020 tercatat 1904 kasus baru 30 Juli 2020 tercatat ada 1904 kasus baru.

Berdasarkan data terbaru per tanggal 5 Juni 2020, total ada 64 pasien positif Covid-19 dengan rincian 37 dirawat, 24 orang sembuh dan dua orang lainnya meninggal dunia. Pada tanggal 12 Juli terdapat 326 pasien positif covid-19 terinfeksi virus corona. Berdasarkan data dari Dinas Kesehatan Kota Malang, penambahan tersebut karena ada transmisi dari kerabat dekat atau keluarga pasien positif Covid-19 (Data Dinas Kesehatan Kota Malang, 2020). Saat ini penyebaran penyebaran virus Covid-19 dari manusia ke manusia menjadi sumber transmisi utama sehingga penyebaran virus menjadi lebih agresif (Susilo, 2020). Untuk mencegah penyebaran wabah covid-19 diperlukan kerjasama Pemerintah, masyarakat, tokoh agama, untuk saling bahu membahu dan saling mengingatkan satu sama lainnya bersama melawan covid-19 (Syafrida, 2020).

Berdasarkan data dari Dinas Kesehatan Kota Malang, penambahan tersebut karena ada transmisi dari kerabat dekat atau keluarga pasien positif Covid19, maka perlu Edukasi yang merupakan salah satu upaya kesehatan masyarakat untuk mencegah penyebaran COVID-19. Promosi kesehatan mengenai cara pencegahan COVID-19 sangat penting diberikan kepada masyarakat. Selain itu, pemberian informasi mengenai cara transmisi dan tingkat keparahan penyakit juga dapat diberikan untuk meningkatkan kewaspadaan masyarakat. Pemberian informasi dapat diberikan melalui media sosial dan media cetak, seperti poster dan pamflet (Audric Albertus, 2020).

Berdasarkan peran di dalam keluarga seorang ibu lebih dekat dalam memberikan bimbingan kepada anggota keluarga khususnya pada anak-anak. Ibu sebagai istri dari suami dan ibu bagi anakanaknya, ibu mempunyai peran untuk mengurus rumah tangga, sebagai pengasuh dan pendidik anak-anaknya, sebagai pelindung dan sebagai salah satu kelompok dari peran sosialnya serta sebagai anggota masyarakat dari lingkunngannya, disampinng itu juga ibu dapat berperan sebagai pencari nafkah tambahan dalam keluarganya (Jhonson, 2010). Oleh karena itu pengabdi tertarik untuk memberikan promosi kesehatan Kesiapsiagaan Menghadapi Virus. Corona (Covid-19) dengan sasaran Ibu-ibu PKK De Cassablanca Residence dan Ibu Kelompok Wanita Katholik Wilayah Yohanes Pemandi Paroki Kesatrian Malang.

\section{METODE}

Kegiatan Program Kemitraan Masyarakat di perumahan De Cassablanca Residence dan Ibu Kelompok Wanita Katholik Wilayah Yohanes Pemandi Paroki 
Kesatrian Malang. dilaksanakan dengan pendekatan peningkatan pemahaman dari para ibu-ibu mengenai promosi kesehatan secara singkat tentang virus corona (Covid19) dan cara pencegahannya melalui media video.

\section{ALAT DAN BAHAN}

Alat dan bahan yang digunakan selama proses kegiatan program kemitraan masyarakat (PKM) ini ialah video tentang Prosedur tata cara memakai dan melepas masker yang benar, pelaksanaan social distancing, cara mencuci tangan yang benar, Etika batuk dan bersin yang benar

\section{METODE PELAKSANAAN}

Metode pelaksanaan kegiatan dibagi menjadi tiga tahap, yaitu persiapan, pelaksanaan, dan evaluasi. Pada tahap persiapan melakukan pendekatan yang dilakukan harus memperhatikan protocol Covid-19 yang meliputi kegiatan sebagai berikut: Pendekatan kepada Ketua PKK De Cassablanca Residence dan Ketua Wanita Katholik Wilayah Yohanes Pemandi Paroki Kesatrian Malang. Memberikan informasi berupa surat permohonan untuk melakukan share video tentang Promosi Kesehatan Kesiapsiagaan Menghadapi Virus Corona (Covid-19) melalui grup Whatshapp.Tahap Pelaksanaan Kegiatan dilakukan dengan diskusi bersama mitra, maka solusi permasalahan mitra yang menjadi prioritas dan harus ditangani secara bersama adalah Pemberian promosi kesehatan Kesiapsiagaan Menghadapi Virus Corona (Covid-19) yang meliputi kegiatan sebagai berikut: Dalam rangka peningkatan pengetahuan mitra, pengabdi melakukan promosi kesehatan tentang kesiapsiagaan menghadapi virus corona (Covid-19) dengan memberikan materi tentang virus corona (Covid-19) dan cara pencegahan penularannya dengan menayangkan video kesiapsiagaan menghadapi virus corona (Covid-19) dengan melalui grup whatsapp. Menunjukkan tata cara yang benar tentang
: cara memakai dan melepas masker yang benar, pelaksanaan social distancing, cara mencuci tangan yang benar, Etika batuk dan bersin yang benar dengan menggunakan media video. Tahap Evaluasi dilakukan bertujuan untuk menilai Pencapaian program yang dilaksanakan mengacu kepada rencana kegiatan yang telah disusun dalam proposal. Evaluasi atas program yang telah dilaksanakan melalui Google form untuk mengetahui keberhasilan kegiatan yang sudah dilaksanakan. Evaluasi dilakukan secara sederhana menggunakan google form sebelum share video dan sesudahnya ada peningkatan yang signifikan pengetahuan sasaran sebelum dan sesudah share video.

\section{HASIL DAN PEMBAHASAN}

Hasil kegiatan dari PKM yang berjudul "Media Promosi Kesehatan Kesiapsiagaan Menghadapi Virus Corona (Covid-19)" dipaparkan dalam tabel 1.

\section{Tabel 1. Hasil kegiatan PKM}

\begin{tabular}{|c|c|c|c|c|}
\hline $\begin{array}{l}\mathbf{N} \\
\mathbf{O}\end{array}$ & WAKTU & $\begin{array}{l}\text { KEGIATA } \\
\mathbf{N}\end{array}$ & $\begin{array}{l}\text { PESERT } \\
\text { A }\end{array}$ & $\begin{array}{l}\text { PENANGGUNG } \\
\text { JAWAB }\end{array}$ \\
\hline 1 & $\begin{array}{l}20-08- \\
2020\end{array}$ & $\begin{array}{l}\text { Pendekata } \\
\text { n Sosial } \\
\text { (Sosialisas } \\
\text { i PkM } \\
\text { kepada } \\
\text { Ketua } \\
\text { PKK RT } \\
\text { 05 RW 05 } \\
\text { dan Ketua } \\
\text { RT 06 RW } \\
\text { 05 De } \\
\text { Cassablanc } \\
\text { a Residence } \\
\text { dan Ketua } \\
\text { WK } \\
\text { Ranting } \\
\text { wilayah } \\
\text { Yohanes } \\
\text { Pemandi } \\
\text { Paroki } \\
\text { Kesatrian } \\
\text { Malang }\end{array}$ & $\begin{array}{l}6 \\
\text { (Enam) } \\
\text { orang } \\
\text { terdiri } \\
\text { dari: } \\
- \\
\text { Pengabd } \\
\text { i } 3 \text { orang } \\
\text { Ketua } \\
\text { PKK RT } \\
\text { 05 = 1 } \\
\text { orang } \\
\text { Ketua } \\
\text { PKK RT } \\
\text { 06 = 1 } \\
\text { orang } \\
\text { WK } \\
\text { Ranting } \\
\text { wilayah } \\
\text { Yohanes } \\
\text { Pemandi } \\
= \\
\text { orang } 1\end{array}$ & $\begin{array}{l}\text { 1. Emy } \\
\text { Sutiyarsih, } \\
\text { S.Kep.,Ns.,M } \\
\text {.Kes } \\
\text { 2. Ns. Elizabeth } \\
\text { Yun Yun } \\
\text { Vinsur, } \\
\text { M.Kep } \\
\text { 3. Elli Lea P, } \\
\text { SST }\end{array}$ \\
\hline 2 & $\begin{array}{l}22-08- \\
2020\end{array}$ & $\begin{array}{l}\text { Penayanga } \\
\mathrm{n} \quad \text { Video } \\
\text { tentang } \\
\text { Media } \\
\text { Promosi } \\
\text { Kesehatan } \\
\text { Kesiapsiag } \\
\text { aan } \\
\text { Menghada }\end{array}$ & $\begin{array}{l}\text { Anggota } \\
\text { PKK RT } \\
05=46 \\
\text { orang } \\
\text { Anggota } \\
\text { PKK RT } \\
06=42 \\
\text { orang }\end{array}$ & $\begin{array}{l}\text { 1. Emy } \\
\text { Sutiyarsih, } \\
\text { S.Kep.,Ns.,M } \\
\text {.Kes } \\
\text { 2. Ns. Elizabeth } \\
\text { Yun Yun } \\
\text { Vinsur, } \\
\text { M.Kep }\end{array}$ \\
\hline
\end{tabular}




\begin{tabular}{|c|c|c|c|c|}
\hline & & $\begin{array}{l}\text { pi Virus } \\
\text { Corona } \\
\text { (Covid-19) }\end{array}$ & $\begin{array}{l}\text { Anggota } \\
\text { WK } \\
\text { Ranting } \\
\text { wilayah } \\
\text { Yohanes } \\
\text { Pemandi } \\
=\quad 20 \\
\text { orang }\end{array}$ & $\begin{array}{l}\text { 3. Elli Lea P, } \\
\text { SST }\end{array}$ \\
\hline 3 & $\begin{array}{l}24-08- \\
2020\end{array}$ & $\begin{array}{l}\text { Penayanga } \\
\text { n Video } \\
\text { tentang } \\
\text { Media } \\
\text { Promosi } \\
\text { Kesehatan } \\
\text { Kesiapsiag } \\
\text { aan } \\
\text { Menghada } \\
\text { pi Virus } \\
\text { Corona } \\
\text { (Covid-19) }\end{array}$ & $\begin{array}{l}\text { Anggota } \\
\text { PKK RT } \\
05=46 \\
\text { orang } \\
\text { Anggota } \\
\text { PKK RT } \\
06=42 \\
\text { orang } \\
\text { Angggota } \\
\text { WK } \\
\text { Ranting } \\
\text { wilayah } \\
\text { Yohanes } \\
\text { Pemandi } \\
=\quad 20 \\
\text { orang }\end{array}$ & $\begin{array}{l}\text { 1. Emy } \\
\text { Sutiyarsih, } \\
\text { S.Kep.,Ns.,M } \\
\text {.Kes } \\
\text { 2. Ns. Elizabeth } \\
\text { Yun Yun } \\
\text { Vinsur, } \\
\text { M.Kep } \\
\text { 3. Elli Lea P, } \\
\text { SST }\end{array}$ \\
\hline 4 & $\begin{array}{l}26-08- \\
2020\end{array}$ & $\begin{array}{l}\text { Penayanga } \\
\text { n Video } \\
\text { tentang } \\
\text { Media } \\
\text { Promosi } \\
\text { Kesehatan } \\
\text { Kesiapsiag } \\
\text { aan } \\
\text { Menghada } \\
\text { pi Virus } \\
\text { Corona } \\
\text { (Covid-19) }\end{array}$ & $\begin{array}{l}\text { Anggota } \\
\text { PKK RT } \\
05=46 \\
\text { orang } \\
\text { Anggota } \\
\text { PKK RT } \\
06=42 \\
\text { orang } \\
\text { Anggota } \\
\text { WK } \\
\text { Ranting } \\
\text { wilayah } \\
\text { Yohanes } \\
\text { Pemandi } \\
=\quad 20 \\
\text { orang }\end{array}$ & $\begin{array}{l}\text { 1. Emy } \\
\text { Sutiyarsih, } \\
\text { S.Kep.,Ns.,M } \\
\text {.Kes } \\
\text { 2. Ns. Elizabeth } \\
\text { Yun Yun } \\
\text { Vinsur, } \\
\text { M.Kep } \\
\text { 3. Elli Lea P, } \\
\text { SST }\end{array}$ \\
\hline 5 & $\begin{array}{l}2 \mathrm{x} / \mathrm{ming} \\
\mathrm{gu} \\
\text { selama } \\
1 \text { bulan }\end{array}$ & $\begin{array}{l}\text { Penayanga } \\
\text { n Video } \\
\text { tentang } \\
\text { Media } \\
\text { Promosi } \\
\text { Kesehatan } \\
\text { Kesiapsiag } \\
\text { aan } \\
\text { Menghada } \\
\text { pi Virus } \\
\text { Corona } \\
\text { (Covid-19) } \\
\text { melaui } \\
\text { status } \\
\text { whatsapp } \\
\text { para } \\
\text { pengabdi. }\end{array}$ & $\begin{array}{l}\text { Masyara } \\
\text { kat }\end{array}$ & $\begin{array}{l}\text { 1. Emy } \\
\text { Sutiyarsih, } \\
\text { S.Kep.,Ns.,M } \\
\text {.Kes } \\
\text { 2. Ns. Elizabeth } \\
\text { Yun Yun } \\
\text { Vinsur, } \\
\text { M.Kep } \\
\text { 3. Elli Lea P, } \\
\text { SST }\end{array}$ \\
\hline
\end{tabular}

Program Kemitraan Masyarakat pada pertemuan pertama dengan para Ketua PKK dan Ketua Wanita Katholik Ranting Wilayah Yohanes Pemandi tentang Program Kemitraan Masyarakat. Peserta yang hadir 6 (enam) orang pada pertemuan pertama sosialisasi tentang Program kemitraan Masyarakat tentang Media Promosi Kesehatan Kesiapsiagaan Menghadapi Virus Corona (Covid-19) yang akan dilaksanakan di masing-masing grup whatsapp. Hasilnya ada persetujuan dari para Ketua dan diterima dengan senang hati serta mempersilahkan untuk memulai kegiatan.

Program Kemitraan Masyarakat pada pertemuan kedua Penayangan Video tentang Media Promosi Kesehatan Kesiapsiagaan Menghadapi Virus Corona (Covid-19) dilaksanakan di masing-masing grup whatsapp pada tanggal 22 Agustus 2020. Jumlah peserta Anggota PKK RT 05 $=46$ orang Anggota PKK RT $06=42$ orang, Anggota WK Ranting wilayah Yohanes Pemandi $=20$ orang Jumlah Total 108 orang dengan harapan para anggota yang terdiri dari ibu semua akan menerapkan dalam kehidupan sehari-hari baik di rumah, tempat kerja atau didalam keluarga. Peserta yang menyaksikan sejumlah : 42 orang.

Program Kemitraan Masyarakat pada Pertemuan ketiga pada tanggal 24 Agustus 2020 Penayangan Video tentang Media Promosi Kesehatan Kesiapsiagaan Menghadapi Virus Corona (Covid-19) dilaksanakan di masing-masing grup whatsapp. Jumlah peserta Anggota PKK RT $05=46$ orang Anggota PKK RT $06=$ 42 orang, Anggota WK Ranting wilayah Yohanes Pemandi $=20$ orang Jumlah Total 108 orang dengan harapan para anggota yang terdiri dari ibu semua akan menerapkan dalam kehidupan sehari-hari baik di rumah, tempat kerja atau didalam keluarga serta akan menyebarluaskan informasi yang diterima melalui media video atau menyebarluaskan videonya ke teman atau saudara sehingga informasi ini akan semakin tersebar luas. Peserta yang menyaksikan sejumlah : 52 orang

Program Kemitraan Masyarakat pada Pertemuan ke empat pada tanggal 26 Agustus 2020 Penayangan Video tentang Media Promosi Kesehatan Kesiapsiagaan Menghadapi Virus Corona (Covid-19) dilaksanakan di masing-masing grup whatsapp. Jumlah peserta Anggota PKK RT $05=46$ orang Anggota PKK RT $06=$ 42 orang, Anggota WK Ranting wilayah 
Yohanes Pemandi $=20$ orang Jumlah Total 108 orang dengan harapan para anggota yang terdiri dari ibu semua akan menerapkan dalam kehidupan sehari-hari baik di rumah, tempat kerja atau didalam keluarga serta akan menyebarluaskan informasi yang diterima melalui media video atau menyebarluaskan videonya ke teman atau saudara sehingga informasi ini akan semakin tersebar luas. Peserta yang menyaksikan sejumlah : 56 orang

Penayangan Video tentang Media Promosi Kesehatan Kesiapsiagaan Menghadapi Virus Corona (Covid-19) melaui status whatsapp para pengabdi. Harapannya akan disaksikan oleh berbagai kalangan dengan khalayak yang lebih banyak sehingga informasi tentang Media Promosi Kesehatan Kesiapsiagaan Menghadapi Virus Corona (Covid-19) dapat disebarkan informasinya ke lebih banyak masyarakat dan dapat meningkatkan kesadaran untuk menerapkan dalam kehidupan sehari-hari.

Kegiatan PKM ini telah terlaksana dengan baik yang telah didukung melalui keterlibatan para ibu-ibu anggota PKK dan Anggota Wanita Katholik Ranting wilayah Yohanes Pemandi. Peran seorang ibu dalam keluarga sangatlah penting. Setelah dilaksanakannya kegiatan ini, para ibu diharapkan untuk selanjutnya dapat menyebarluaskan informasi yang didapat dari tayangan video yang sudah dilihat. Hasil kajian data yang telah didapat pada saat kegiatan PkM ini ibu-ibu menunjukkan ada peningkatan pengetahuan tentang Promosi Kesehatan Kesiapsiagaan Menghadapi Virus Corona (Covid-19). Dengan adanya program PKM ini, diharapkan ibu-ibu akan meningkatkan kesadaran dan kedisiplinan masyarakat melalui program-program pemberdayaan masyarakat yang berkaitan Promosi Kesehatan Kesiapsiagaan Menghadapi Virus Corona (Covid-19). Ibu-ibu menjadi fokus utama dalam kegiatan $\mathrm{PkM}$ ini. Dengan adanya kegiatan ini, diharapkan ibu-ibu dapat meningkatkan kemampuan serta pemahaman terkait Promosi
Kesehatan Kesiapsiagaan Menghadapi Virus Corona (Covid-19). Selain itu diharapkan ibu-ibu dapat melakukan penyebarluasan informasi yang didapat kepada masyarakat sekitar setelah menyaksikan tayangan video pada kegiatan $\mathrm{PkM}$ ini. Hal ini diharapkan dapat memaksimalkan informasi dan dapat membantu mengubah pola pikir dan pola hidup sehat masyarakat untuk meminimalkan terjadinya penyebaran penularan virus corona (Covid-19).

Program PkM ini diharapkan dapat membantu meningkatkan derajat kesehatan masyarakat melalui peningkatan pengetahuan para ibu-ibu karena para ibu yang sangat berperan pada pendidikan di tingkat keluarga. Para ibu juga memiliki jejaring grup sehingga harapannya para ibu ini nantinya juga akan menyebarluaskan video tentang Promosi Kesehatan Kesiapsiagaan Menghadapi Virus Corona (Covid-19) sehingga akan semakin banyak masyatakat yang mendapatkan informasi tersebut.

\section{KESIMPULAN}

Program Kemitraan Masyarakat (PkM) dengan judul "Media Promosi Kesehatan Kesiapsiagaan Menghadapi Virus Corona (Covid-19)" telah terlaksana dengan baik dan lancar. Kegiatan PkM ini mendapatkan respon sangat baik dari ibu-ibu. Kegiatan PkM ini telah mengatasi keresahan para ibu-ibu dalam menghadapi pandemi. Para ibu-ibu sebagai sasaran utama kegiatan PkM untuk selanjutnya kami berharap informasi ini dapat diterapkan di dalam keluarga dan disebarluaskan ke masyarakat di sekitarnya

\section{DAFTAR PUSTAKA}

Audric Albertus. (2020). Edukasi Dan Promosi Kesehatan Coronavirus Disease $2019 \quad$ (Covid-19) https://www.alomedika.com/penyak it/penyakit-infeksi/coronavirusdisease-2019-covid-19/edukasi-danpromosi-kesehatan 
Kurniandari, Rohmana. (2020). UPDATE Sebaran Virus Corona Indonesia. https://ternate.tribunnews.com/2020 /07/30/update-sebaran-virus-coronaindonesia-30-juli-jatim-jateng-danjabar-catat-kasus-sembuhterbanyak.

L, Jhonson dan Leny, R.2010. Keperawatan Keluarga. Yogyakarta : Nuha Medika.

Syafrida, Hartati. (2020). Bersama Melawan Virus Covid-19 di Indonesia. Jurnal Sosial \& Budaya Syar-i

Susilo Adityo dkk. (2020). Coronavirus Disease 2019: Tinjauan Literatur Terkin. Jurnal Penyakit Dalam Indonesial Vol.7.No.1/Maret 2020. Departemen Ilmu Penyakit Dalam Fakultas Kedokteran Universitas Indonesia-RSUPN dr. Cipto Mangunkusumo, Jakarta

WHO.(2020). WHO Driector-General's remarks at the media briefing on 2019-nCov on 11 February 2020. Cited Feb 13rd 2020. Available on: https://www.who.int/dg/speeches/det ail/who-director-general-s-remarksat-the-media-briefing-on-2019-ncovon-10-february-2020 